\title{
Victor Marsh
}

\author{
Bent kid, straight world: life writing and the reconfiguration \\ of 'queer'
}

\begin{abstract}
Michel Foucault would have it that 'the critique of what we are is at one and the same time the historical analysis of the limits that are imposed on us' and 'an experiment with the possibility of going beyond them' (Foucault 1984). I argue that, rather than upholding a fixed notion of self that is culturally produced, historically situated and politically defended, in its quest for continuing liberation queer consciousness reaches beyond the cultural framings that have produced it to access technologies of selfhood unauthorised by dominant cultural discourses. This inquiry has the potential to recuperate areas of lived experience shut down by the 'culture of insult' (Eribon 2004). Following Paul John Eakins' proposal that identity is a narrative construction, and the project of the self is malleable, then autobiographical writing has become the genre par excellence for recovering and reevaluating experience filtered from awareness by hostile cultural framings and may thus contribute to reconfiguring and re-integrating aspects of identity. This has implications beyond the political struggle for civil rights, reaching into newly emergent configurations of post-secular spirituality. I will discuss how the creative praxis of life writing can recuperate lost parts of the self otherwise silenced by the dominant culture, including those not authorised by normative religious discourse, with excerpts from my work in progress, The Boy in the Yellow Dress, a memoir cast in the first person.

Keywords: interpellation, subjectivity, life writing, queer spiritual autobiography, technologies of self
\end{abstract}

While preparing an earlier version of this article as a conference paper [1] I was heartened to read what I took to be the conference's motto; namely: that the job of the scholar is to: 'subject structures of power, knowledge, and practice to critical scrutiny'. In my research and my scholarly and creative writing I have been concerned with the interrogation of compulsory notions of identity. As a child I soon became aware that one was expected, nay required, to be 'Christian' - an identification that was culturally and coercively imposed as the complete answer to all the directions my spiritual inquiries could possibly ever take. By that time I had also become aware that the masculinist codes that applied to my putative gender marked me out as decidedly deviant (sissy, pansy, homo, poofter, queer) and that the compulsory form that my sexuality should follow was to be strictly heterosexual (and that there were coercively sanctioned ways to make me conform to that culturally provided model).

To cut a very long story short (66 years at the last count) I can say that, dissatisfied with the options on offer, I became an exile within my own country, alienated not only from the Church, from psychological Medicine and the Law, 
but from Family too, within which I had to take up a position of hiding (this was later to be christened 'the closet'), especially after a brutal rejection at the hands of my father, which really knocked me for a loop.

I am working on a memoir (The Boy in the Yellow Dress) that recounts this sense of exile and some of the confused pathways I pursued through extreme psychological and ontological disorientation. As I headed inexorably towards self-destructive oblivion, I dealt very poorly with all the attendant issues of gender and sexual confusion and followed a predictable spiral into drugs - in my case, the psychedelic variety. The memoir also reveals, eventually, the way I find out of what I could advisedly term these 'dead' ends, into more lifeaffirming pathways.

Along the way I discovered that meaning and power are inextricably related in contemporary constructions of identity, and that resistance to culturally prescribed models of identification has important political ramifications.

Michel Foucault would have it that 'the critique of what we are is at one and the same time the historical analysis of the limits that are imposed on us' AND 'an experiment with the possibility of going beyond them' (Foucault 1984: 32).

I would now argue that, rather than upholding a fixed notion of self that is culturally produced, historically situated and politically defended, in its quest for continuing liberation my nascent queer consciousness has reached beyond the cultural framings that have produced it to access technologies of selfhood that re-open neural pathways shut down by what Foucault's biographer Didier Eribon (2004) calls the 'culture of insult' and the serious limits inherent in the construction of the 'homosexual' as a religious pariah. Noting the earlier work done by scholar of autobiography, Sidonie Smith, I situate my life writing praxis within this project of recuperation, even if Smith might be surprised to find her work applied to post-secular spiritual inquiry.

In my experience, both psychological medicine and conventional religion operated within an economy of power that sanctioned strictly limited possibilities for exploration and expression in modern culture as I encountered it. The authorised forms that identity - and meaning itself - could take, were prescribed by a dominant, privileged class in order to 'normalise' its majoritarian practices and shore up the shared beliefs that provide the foundation for complex, interlocking systems of domination. As JF Lyotard insisted: 'knowledge and power are simply two sides of the same question: who decides what knowledge is, and who knows what needs to be decided?' (Lyotard 1986: 9).

Dominant expectations of what it might be possible for a so-called 'homosexual' to know are part of this complex economy of power, produced by those 'regimes of truth' described by Foucault, that constitute 'a set of rules by which truth is produced' (Foucault 1994: 297). According to those rules, 'homosexuality' was supposed to represent a degenerative failure in normal psychological development and - in the terms from another, dominant discourse that impacted my formative years - a religious pariah. By drawing on spiritual resources in the pursuit of self-knowledge, independent queer researchers inquiring into the roots of self are rehearsing what Judith Butler calls 'unforeseen and unsanctioned modes of identity' (Salih 2004: 10), effectively 'changing the subject' and disrupting authorized versions of masculinity and these disempowering constructions of the 'homosexual' as religious pariah. 
"the violence of exclusion narrows the categories by which subjects "qualify" for full human status' (2004: 12). Such forms of epistemic and social violence have serious consequences in the lives of people trying to come to terms with their sexuality, so there are quite pragmatic reasons why these normative discourses need to be interrogated. It still comes as a surprise to some queer folk that religion could hold much interest for people not inclined to repudiate their sexuality, just as much as it surprises some church folk to find that there are queer folk in their midst - in effect 'que(e)rying religion' (Comstock \& Henking 1997) - for whom issues of sexuality and gender non-conformity do not preclude their intelligent engagement with religious teachings and practices. Further, when freed up from the hegemonic control of institutionalised religions, post-secular forms of spiritual inquiry may produce quite original configurations of queer identity that reach beyond conventional forms of religious practice. Queer folk may even become what Peter Savastano terms 'virtuosi' at the 'holy art of bricolage' (Savastano 2007).

\section{Interpellation}

I want to lead into the first excerpt from my memoir with reference to the theories of Louis Althusser. In his essay 'Ideology and Ideological State Apparatuses (Notes towards an Investigation)', Althusser explores the relationship between the state and its subject citizens, and analyses its modes of (re)producing power and ideology. He defines ideology as 'the imaginary relationship of individuals to their real conditions of existence' (Althusser 1972: 162). Althusser saw ideology functioning as a mediator between systems of power and individuals. It allowed for hegemonic power to reproduce itself not only by obscuring traditional forms of repression but also by cleverly incorporating individuals into the power structure.

Althusser developed this relationship between domination and subjugation by introducing what he called interpellation, the process whereby individuals recognize themselves as subjects through ideology, and he described how subjects become complicit in their own domination. In the simplest of examples: a police officer shouts out: 'Hey, you there!' in public. Hearing this calling out, or interpellation, an individual turns around, and 'by this mere onehundred-and-eighty-degree physical conversion', Althusser wrote, 'the individual becomes a subject' (1972: 174).

In the act of acknowledging that it is indeed he/she who is being addressed, the individual thus recognizes his/her subjecthood and not only accepts his/her place within the social, political and legal order but in effect endorses the ideology that empowers the order. (The notion of interpellation as a process was, of course, further developed by Michel Foucault and Judith Butler.) The exhortation could be to 'know your place!'

Althusser emphasizes the ubiquity of ideology and interpellation by noting how subjects are consistently and continuously constituted by Ideological State Apparatuses (ISAs) such as the family, educational institutions, and media such as literature, radio and television. I would add religion to the mix, even though its influence is said to be waning.

In her discussion of the process, Judith Butler later raised the possibility of failed interpellations [2]. Subjects who would reposition their subjectivities beyond such hostile constructions must perforce resist and disobey the ideology embedded in the interpellative 'name game' to assert and inscribe affirmative subject positionings outside the ideologies that would render their lifeways 
sinful, pathological, othered, excluded, thus becoming what Gillian Whitlock calls 'disobedient subjects' (Whitlock 1996).

In order to provide a sense from first hand testimony how this process impacts at the level of the individual, here is an excerpt from my memoir-a sequence titled 'The Name Game'.

\section{The Name Game}

What's secret doesn't stay that way for long.

A friend and I - let's call him Daniel - have started sneaking out at night to prowl the local lovers' lane, on the sandy tracks down near the river. On a Friday or Saturday we can be sure to come across a few cars snuggled under the low, scrubby paperbark trees. We're hoping to find out more precisely what goes on between men and women there but are afraid to trigger pursuit by hostile young men, angry at having their coitus interrupted. Reluctant to actually peer in the steamy windows, Daniel and I are left to our own imagination as to what kinds of acts might be underway. One Saturday night we find a discarded condom and take it home. I know that it's called a 'prophylactic' - commonly known as a 'franger', or 'French letter' - and that it's used to guard against disease as well as impregnation. We take the rubber back to my place, wash it out in the bathroom sink and roll it in some paper towels to dry, before my pubescent friend decides to try it on for size.

At thirteen, these are mysteries for which we have only rudimentary instruction. Daniel is a short boy with an inordinately large penis that I soon discover features a fleshy, purple head. When it gets hard its large hole drips with sticky fluid. We haven't worked out that we could masturbate yet, so our fumbling repertoire consists of looking and touching and whispered debates about what we could do.

One afternoon, alas, my sister catches us comparing notes in the enclosed room off the back verandah-nothing hard-core, I recall, but we do have our individual members out of our shorts for mutual inspection.

Valerie turns on her heel and storms through the house, screaming 'HOMOSEXUAL' at the top of her lungs. Not all compressed, as it reads on the page, but rolled out, syllable by outraged syllable: HO - MO - SECKS - SHOO - ALL, the emphasis bunched on the third syllable, like she wants the forbidden fact to splatter onto the walls and hang there dripping for days, so that no one can fail to recognise what I am reluctant to have anyone, even Daniel, see.

I cringe, dreading the imminent discovery in which denial will be unmasked and I will be caught in shame's glaring headlights. Daniel slinks out the side door.

There's no one else home this afternoon, but Val knows she has something on me and she might tell them later, so the threat hangs ready to unload, like the missiles: 'sissy boy', 'fairy', 'pansy', 'poofter', 'queer' that I have ducked until now, hoping they won't home in on me.

The next few days are fraught with caution. My phone calls to Daniel's house meet with a frosty reception-his mother won't even call him to the phone. What has he told her? Does 
he suspect that I am more into these pre-love games than he is? Now that he has caught a whiff of what this might imply about his own manliness, he withdraws completely from our pre-love games. I am popular in school, and active in sports, so to a degree I am shielded from suspicion, but I fear my cover has thinned dangerously.

It isn't as if the word is foreign, exactly. If Val already knows what it means at ten, I must too, at thirteen. 'Homo' is the short form and, even though I have been avoiding it, somewhere along the line I have learned not only that its nastiness applies to me but now, especially as the physical aspect is starting to manifest, what it might 'mean'. It has never landed so squarely on its target like this before, let alone in (semi-)public. EEEEEEEEEE-YOOOWWW! Like a fighter plane in those war comics, diving in to deposit its deadly cargo... SCHPLATT!

That name. It casts me in a role in a script already written. 'Places, please'. But when did I audition for this part? And did I miss the segue, when something I might like to $d o$, if I ever get the chance, becomes an entire identity, placing me precisely in a taxonomy of types, like an insect impaled on a pin in some dusty zoological museum? If 'this', it tells me, then certainly not 'that'. My story will be written only on the margins, a life lived outside the mainstream where the real people do their thing.

My Yankee grandmother has a Webster's on a stand. The entry after 'Ho.mo sa.pi.ens' ('the scientific name for the only living species of the genus Homo') is:

ho.mo.sex.u.al adj. of, or characterized by, sexual desire for those of the same sex.

$n$. a homosexual individual. Opposed to heterosexual.

This identity seems ready-made, then, and I suspect it's loathsome. Will I become one of those invidious caricatures who mince across the screen occasionally, at the pictures? (No handsome leading man takes another man into his arms for a kiss, or more.)

I do some furtive research in a public library, uncovering the term in a volume by von Krafft-Ebing, a book so grim it ought to be enough to drag me from my wayward path back onto the straight (and narrow). This is what I have to go on: von Krafft-Ebing, R.

Psychopathia Sexualis with especial reference to the Antipathic Sexual Instinct. A Medico-Forensic Study. 1924. I flip to the index at the back: p. 616. There I am, right after 'Hermaphroditism, psychical':

Homosexuality (vide Antipathic sexuality), p. 286

'Homosexual feeling as an abnormal congenital manifestation'

followed closely by:

hysteria

then:

ideal sadism, 118

Impotence, 13

Immorality, 502

Incest, 612

Injury to women, 105 
and

Insanity among the Scythians, 302.

So that's the company I keep!

A little further on, right after a lengthy entry on 'masochism', is the dreaded:

Masturbation, consequences of, 286.

Then follows a lengthy entry on 'pederasty', and various

references regarding:

pathology, special, 462

and

psychopathological cases, 554

under:

sexual instinct, homosexual, 282

---perversions of, 79, 462

I must be seriously sick! Flicking back to the listings for 'sodomy', I go to page 561, where the German expert kindly has listed for my perusal:

7. Unnatural Abuse (Sodomy).

Sub-section 7 (a) records information on

Violation of Animals (Bestiality).

So this is my condition-a 'mental condition', in fact, an 'abnormal perversion'. I am not so much a legal problem, I see, as I am a specimen for the scientific study of 'Inverts'. My sister has spoken with more authority than she knew. If she and her scientific allies already know me better than I know myself, are they telling my future, too? On page 573, I find that

for 'many neuropathic individuals' (and 'Urnings' are almost always 'neuropathic'):

Before them lies mental despair,-even insanity and suicide,-at the very least, nervous disease; behind them, shame, loss of position, etc.

Nothing to look forward to but despair, insanity and suicide. I search out 'neurasthenic' in the index, and flip through some case studies. For example, the one on 144:

hysteria gravis

... there was no amnesia. Thoroughly virile. Decent appearance. Genitals normal. Short imprisonment.

Imprisonment! But you said I was not a criminal, I was an 'irresponsible insane person'. From being a psycho-medical disorder I have achieved the status of criminal offender, too: a sexual, medical and social outlaw.

Moreover, Victor Marsh, aged thirteen, has already found his way onto the path to perdition, for on page 447, I read:

puberty teaches the youthful sinner to know his true sex soon enough... the homosexual act committed after

puberty has set in, is the decisive step in the wrong direction. A moral outcast, too. Even the scientist names me as sinner.

There were a lot of messages folded in Valerie's accusation: this is shameful; you had better hide; there is danger in this becoming public knowledge; there are other people who don't need to hide; you're degenerative, sick; you're 'one of nature's mistakes'. 
This naming project is part of a wider conspiracy to call me into line. I have been warned not to gush. I shouldn't use my hands when I talk. In fact, it is advisable not to be too 'expressive'; too 'theatrical'. I should be careful not to flap my wrists, nor to stand with my hands on hips (that's a dead giveaway). My brother recommends that if you clench your teeth, the muscles make your jaw look stronger. The size of your biceps matters.

There's a way to walk like a man does, too, but I am not getting that right, I'm a little 'light in my loafers'. And the way your voice goes up at the end of the sentence? You need to bring it down, level it out. Train the voice into a lower register. Better still, don't talk so much. In fact, it would be better if you dumped that enthusiasm altogether.

So here is a first person example of the notion of interpellation, and how it works to coerce the individual into conformity... or not. This process - an insidious indoctrination for a developing psyche - positions subjects ideologically within the social order and propagates a 'violence of exclusion' that is not only conceptual but can lead all the way to actual physical assault.

I propose that the praxis of life writing provides an opportunity to resist and 'talk back' (hooks 1990b) to this set of hostile constructions. As bell hooks would have it: 'for us, true speaking is not solely an expression of creative power, it is an act of resistance, a political gesture that challenges the politics of domination that would render us nameless and voiceless' (hooks 1990a: 338).

\section{Re-configuration}

I want to bridge into the next excerpt with another, rarely explored piece of theoretical framing from Erich Fromm (1900-1980), the German-born social psychologist who worked mostly in the US.

Fromm was one of the first in his field to address the relationship of psychoanalysis to the practices of Zen Buddhism, and has helped me understand how dominant, homophobic metanarratives participate in the process of occluding the possibility of queer spirituality, at the level of the individual. In his long essay 'Psychoanalysis and Zen Buddhism', Fromm wrote:

[E]xperience can enter into awareness only under the condition that it can be perceived, related and ordered in terms of a conceptual system and of its categories. This system is in itself a result of social evolution. Every society, by its own practice of living and by the mode of relatedness, of feeling, and perceiving, develops a system of categories which determines the forms of awareness. This system works, as it were, like a socially conditioned filter ... (Fromm 1960: 99)

And, he asserts, 'experience cannot enter awareness unless it can penetrate this filter'.

Writing autobiographically, then, is a way of finessing Fromm's filter effect, giving me a chance to recognise and recuperate areas of lost experience cancelled out by limited social indoctrinations giving voice to what has been 
silenced by dominant discourses. This praxis reaches beyond the frame of the familiar coercive constructions of my own culture, where I was subject to the violence of various forms of exclusion, including epistemic exclusion, to find integration, various forms of healing and original and hybrid ways of reconfiguring selfhood.

We are familiar with the tropes of 'coming out' and coming to terms with one's sexuality in much life writing and fiction from queer writers, but little attention has been paid to the technologies of selfhood accessed through spiritual practice. So, to take my discussion a notch or two further I include another scene from my memoir. The book opens at my father's funeral and, early in the first chapter, as I am preparing my parents' house for sale, I find a photograph that triggers a chain of reminiscences. It's a photo of a boy - it must be me, at 3 or 4 years of age - and it was taken in the sitting room of the first house I remember living in ...

\section{Child's play}

In the formal sitting room, the curtains are drawn. Thick carpet and upholstered furniture muffle all sound. The boy seeks out this place to be alone. But first, he goes to the room across the hall, to the cupboard where his mother's dresses hang, bereft of form, awaiting their brief moments of coming to life (all fullness and motion, then).

He climbs up into the wardrobe to reach for one of these, which glows, special to him. It's dappled yellow, mixed with green. He clambers down from the cupboard and slips the gown over his head. Hanging loose around him, its folds cascade onto the floor, silky texture cool where it skims his skin.

Women's voices murmur in the kitchen.

Suitably attired, the boy returns to the sitting room where he twirls slowly in the half-light, head cocked, gazing down at the skirt as it rises around him in the air. He settles down to sit on his heels, entranced by the golden glow, and spreads the ample folds of fabric in a perfect circle around him on the floor.

Eyes closed, he rests in peace, ears singing in the silence. Dust motes float, lazy, in the light.

Sometime later, the dress is returned to its waiting place.

But one day, when he reaches into the cupboard, the cool fabric isn't there to meet his touch. He wants to catch the magic feeling-wrap it around him, disappear. He tries the cupboard again, but even the most careful iteration of his actions fails to make the dress appear. In its place, a heavy feeling drags in his chest.

Another day: The washhouse, in the back yard. A copper tub squats above the fireplace where water is boiled to clean the clothes, on Mondays. Sifting through the ashes, he finds the charred remains of the dress... this lovely thing banished to dirty dust in his hands, his magic carpet gone.

In the fowl run, a hen murmurs cluck cluck, slow. The heavy feeling returns to roost in him as, inside the house, a door clicks shut. 
They never said anything about the dress. They must have seen me slip into the sitting room, in an altered state, eager to catch my ride back home. Perhaps it signaled something not quite right to them-something so bad, in fact, they could never speak of it. They burned the dress and allowed its absence to resonate unexplained through my days.

Looking at the photo now, some forty years on, the whole scene comes back to me-the darkened room, the plush furniture, the fabric cool against my skin. But most of all I recall the familiar presence of the light, and the ease with which a boy could draw it around him and disappear. He hadn't ever been taught to do that. His naïve play invoked a comfort, not from memory, but woke it somehow from another space, to which he was connected, within.

What is the meaning of this child's play? Will the reader expect the life story of a 'transvestite'? You would be right if you assumed that, having the dress so thoroughly banished from his playmaking, the boy is left with a sense of loss, but what is it that he loses, and what will it take to restore him to the lost state of wholeness? And what atavistic impulse could lead a three-year-old boy to re-create a ritual more common in Siberian shamanism than in suburban West Australia?

At school, he will drawn to the intricate games with skipping ropes but, ears red with the shaming cry of 'sissy', he will shooed away, in the strictly segregated playground, to the boys' area, to be tortured by the bruising bounce of a cricket ball. Sex has not reared its ugly head yet (whatever Freud might say). Gender has, certainly: Boys don't do that!

But he doesn't want to transform himself into a girl, nor does he develop a fullblown fetish for dresses. What he yearns for is the easy access to the light, that state of undifferentiated unity which preceded this rigid bifurcation: if this, not that; you can't be both. For, being with the light was being with his self. And it is through gender, that his exile from the place of peace - his 'homeland', you might call it - will be made complete.

I suggest that what is queer about the sissy boy is his recall of, and yearning for, the lost spaces of the self that the forces of cultural conditioning are configured precisely (and coercively) to make him forget. The primary state he accesses is undifferentiated awareness, the field of consciousness from which his personal mind has barely begun to emerge; through gender he will be initiated into a secondary order and later, later, through sex, into a tertiary order of being. But he remembers the primary state, of unity, not separation. Dislocated thus, he is rendered blank, a tabula rasa, without this primal memory, to have his being scripted, written over. He is perverse, this sissy child, and his queer instinct will continue to remind him that this is not the whole story.

\section{Re-locations}


The narrative moves through further stages of dislocation and, eventually, relocation with the help of the patient instruction of a guru figure whom I meet at a crucial turning point in the narrative. Now, with the perspective of nearly forty years meditation practice, I have been able to re-visit scenes from my earlier life and recover zones of lost experience for which, following Fromm's filter effect, there was simply no reinforcement from within my own culture to imprint. If my little moments of insight had occurred within acceptable frameworks, such as a 'confirmation', say, or a bar mitzvah, perhaps they would have registered, at least as socially sanctioned. Although I vaguely recalled the incident with the dress, the experience was lost. A door had been closed, and sealed shut with shame. I recovered several such incidents through this autobiographical writing praxis and that recovery, rather than repositioning my subjectivity within the fold of social approbation, served instead to relocate the centre of my consciousness within a deeper field of awareness than that offered by the warm glow of normativity. Marginalisation can be a blessing.

Unless I had been able to re-inhabit that space [3] through meditation practices (sustained over many years) I wouldn't have recognised its significance. Gradually, the meaning of this lost zone of experience began to dawn on me and I am now exhuming further incidents of spontaneous spirituality, finally beginning to recognise their intrinsic value though none of them occurred within conventional religious settings.

\section{Some further theoretical reflections}

David Halperin has discussed how the political work around the AIDS epidemic has 'multiplied the sites of political contestation and resistance beyond such traditional arenas as the electoral process, the power structure, and the industrial economy' (Halperin 1995:28). Halperin agreed with Foucault's insight that 'power's success is proportional to its ability to hide its own mechanisms' (Foucault 1978: 86). Halperin and others may not have realised that the resistance and resistance might now begin to include the resources available from so-called 'spiritual' work. Autobiographical texts that work to recuperate the lost parts of self, add to the multiplication of 'sites of contestation' then, by resisting the unquestioned exclusivist claims to knowledge authorised by the hegemonic constructions of meaning operated by religion and/or normative psychology.

Discussing subaltern studies, Vinay Lal (2010) raised the issue of complicity in one's subordination that Judith Butler has also explored. This suggests to me that many queer folk might now be re-considering that very issue in their own religious subordination. Life writing contests pre-scripted identities and intervenes to re-order toxic, hostile constructions. Hence the genre of the 'queer spiritual autobiography', identified by Stewart (2002) who has laid the groundwork for establishing characteristics of the genre. A cache of texts in the genre testifies to the recovery of the value of such experience, even in the lives of us pariahs. [4]

\section{Relevant literary theories}

Literary scholarship has recently come around to interesting theoretical positions that are relevant to my discussion. The first of these has to do with the opportunity provided by life writing to produce a counter-narrative to how hostile discourses have tended to position queer subjectivities. In an early book on women's autobiographical practice, Sidonie Smith pointed out how women 
have effectively used autobiography as a 'prominent ground for cultural critique and resistance':

While negotiating various identifications (of gender, race, class, ethnicity, sexuality), they discover points of resistance to the integumentary strains of provided subjectivities. Their contradictory and fluid subject positionings lead them to intervene in those cultural fictions, interrogating, cannibalizing, re-reading the stories to their own purposes. (Smith 1993: 68)

In a later book with Julia Watson, Smith identifies women exploring alternative notions of subjectivity which are based not on the humanist idea of a unique and universal self, but in 'very complex collective identities which feature autobiographical subjects as existing at particular and changing intersections of race, nationality, religion, education, profession, class, language, gender, sexuality, a specific historical moment, and a host of material conditions' (Smith and Watson 1996: 40). They claim that 'the new geography of identity insists that we think about writers in relation to a fluid matrix instead of outworn binary oppositions of male/female or masculine/feminine, etc'.

Smith and Watson build a case for life-writing as a means of critical intervention into post-modern life. They describe 'the many means by which models of acceptable identity are circulated and renewed in society', analysing 'how state, church, school, corporation, government and the advertising industry secure normative subjects in acceptable social relationships' (1996: 12). In specific situations, Smith and Watson say, people may 'choose not to narrate the stories that are prescribed for them', opting instead to 'reframe the present by bringing it into a new alignment of meaning with the past' (12).

Writing autobiographically, then, becomes a resistant strategy for renarrativising the self, an assertive reconfiguration that recovers meaning from the toxic narratives buried within hostile discourses. 'Seizing the occasion and telling the story', say Smith and Watson, 'turns speakers into subjects of narrative who can exercise some control over the meaning of their lives' and this assertion, they say, is 'particularly compelling for those whose personal histories include stories that have been culturally unspeakable' (Smith and Watson 1996: 13-14).

This positioning firmly established that life writing is an amplifier for the voices of marginalised peoples. If we recognise that early writing on queer experience was mostly been concerned with tropes of 'coming of age' and 'coming out', first sexual experiences, the struggle for civil rights, and later, issues raised by the HIV/AIDS crisis, etc., this rationale is familiar territory. My research however, has been concerned with the technologies of selfhood that are accessible through spiritual inquiry, a distinct if sometimes overlapping set of practices that differs in interesting ways from religious belief [5]. Such theoretical groundwork, often laid by feminist scholars, leads into the possibility of introducing tropes of queer identity beyond the hegemonic construction of the homosexual as religious pariah into new possibilities of being and becoming.

Smith notes the destabilisation of old constructions of the self and how autobiography has shaken their 'cultural hold on us', noting how autobiographical subjects are compelled 'to splinter monolithic categories through which they are culturally identified, such as the monolithic category of "woman", and to reassemble various pieces of identity, experience, and knowledge into another kind of subjectivity' (Smith 1993: 61). I am proposing that also applies not only to the ideological prescriptions surrounding protestant 
forms of sexuality but further, that it applies to spiritual research 'unauthorised' by historically privileged and socially sanctioned religious institutional teaching.

\section{Self as narrative}

For it is the very concepts and ideologies underpinning what constitutes a self that are problematised most directly in these new positionings of subjectivity. Recent work by a leading scholar of autobiography supports my position. In the late 1980s, Paul John Eakin, in Fictions in Autobiography, argued for an autobiographical truth that is not a fixed and stable content, but a complicated process of self-discovery and self-creation, recognising that the 'self' of all narrative autobiography is necessarily a fictitious construct. But Eakin, one of the late twentieth century's foremost scholars of autobiography, has moved the theory on from that earlier position to develop the notion of self as narrative. Eakin first tackled the narrative identity thesis that is central to my own discussion: viz., 'that we are or could be said to be a story of some kind' in a 2004 journal article. 'Autobiography', he writes,

is not merely something we read in a book; rather as a discourse of identity, delivered bit by bit in the stories we tell ourselves day in and day out, autobiography structures our living. (Eakin 2004: 122)

Working in the social sciences, Jerome Bruner had used the same notion, writing that: 'the self is a perpetually rewritten story ... in the end we become the autobiographical narratives we tell about our lives' (Bruner 1987: 15). 'Narrative' has become a useful tool in many disciplines, including psychology for, if self is a 'story', it can be told differently, and psychotherapists have exploited the therapeutic potential of re-narrativisation. The Australian psychologist Michael White recognised the therapeutic potential of the narrative approach to self and developed what has become known as 'narrative therapy'. If self is a story it can be told differently, and the narrative therapist works to assist the client in locating 'alternative life narratives'. Susan Nicholson says this is a 'deconstructive' process by which 'the dominant restraining narrative is unmasked and re-examined from a new angle' (Nicholson 1995: 24).

For a pre-eminent scholar in autobiographical theory such as Eakin to embrace this approach was initially quite controversial. The philosopher Galen Strawson was very unhappy with the narrative identity thesis, dismissing it in Ratio as an 'intellectual fashion' in vogue among academics (Strawson 2004: 439) but, rather than backing away, Eakin took up the challenge and re-stated his arguments more fully in his book, Living Autobiographically: How We Create Identity in Narrative (Eakin 2008).

\section{Technologies of freedom}

Queer folk recognise that colonialism is a project operating within as well as across political cultures, and their life experience may lead to insights into how such a project outlaws identity positions that do not conform to the dominator model that colonises possibilities of meaning. To carry out an investigation of the power and influence of the coloniser, and interrogate its ruling principles, the colonised subject (in this case, the putative 'homosexual') needs to become aware of the infiltration of the colonising power within the internal 
infrastructure of his/her own sense of self. This inquiry, according to Michel Foucault, should be 'oriented toward what is not or is no longer indispensable for the constitution of ourselves as autonomous subjects'. Otherwise, he asks:

do we not run the risk of letting ourselves be determined by more general structures of which we may well not be conscious, and over which we may have no control?' ('What is enlightenment?' Foucault 1984: 47)

To Foucault, criticism is 'no longer going to be practiced in the search for formal structures with universal value,' then, but rather as 'a historical investigation into the events that have led us to constitute ourselves and to recognize ourselves as subjects of what we are doing, thinking, saying' (45-6). In contrast to the search for 'formal structures with universal value', Foucault prefers

the very specific transformations that have proved to be possible in the last twenty years in a certain number of areas that concern our ways of being and thinking, relations to authority, relations between the sexes, the way in which we perceive insanity or illness. (Foucault 1984: 46-7)

Foucault characterises what he calls 'the critical ontology of ourselves' as 'a historico-practical test of the limits that we may go beyond, and thus as work carried out by ourselves upon ourselves as free beings' (1984: 47).

The issue of freedom is a critical sub-text in all of the preceding discussion. In Foucault's model, technologies (or 'practices', or 'care of', as he variously termed it) of the self are interlinked with his notion of 'governmentality' - the rationales whereby both individuals and social structures regulate and police norms of thought and behaviour. 'Government' acts as a kind of point of intersection where techniques of domination and technologies of the self meet and interact. According to Foucault, this point of connection is where 'technologies of domination of individuals over one another have recourse to processes by which the individual acts upon him or her self', so it can also be the site where techniques of the self are integrated into the very structures of coercion. Or not. The kind of analysis - or 'critical ontology' - of the forces operating upon oneself, that - in a sense - create one's self, informs a conscious re-appraisal of one's own complicity and co-operation in the practices of domination. Hence the possibility of resistance, in the kind of wilfully and consciously failed 'interpellations', as discussed earlier. The queer child may be able to awaken to the insidious, toxic ideological coercions that have been operating him/her and remove them, root and branch, from the psyche.

\section{In summary}

It has been my experience that through life writing praxis, I can resurrect key areas of experience from my own 'history' that had been filtered out of awareness and significance, previously. In this continuing process I find that I am fulfilling Foucault's dictum that 'the critique of what we are is at one and the same time the historical analysis of the limits that are imposed on us' and 'an experiment with the possibility of going beyond them' (Foucault 1984). And that this resurrection is not only a political, ideological, or theoretical positioning but a reclamation of the possibilities of a richer life and a consciousness more at liberty to investigate and explore without suffocating in 
the miasma of provided identities, including those that emanate from Church, State, Family, Medicine and even from a 'gay community'.

\section{Notes}

1. This article was adapted from a paper given at the Cultural Studies Association of Australasia annual conference: A Scholarly Affair, Byron Bay, NSW, Tuesday 7 December 2010. return to text

2. See Butler's discussion in The Psychic Life of Power (Butler 1997). return to text

3. Vinay Lal (2010) refers to a 'psycho-geography of home'. Christopher Isherwood wrote: 'it is not home that one cries for, but one's home-self' (Isherwood 1971: 285). In Andrew Harvey's translation, the poet Rumi sings of being 'delivered from selfhood': '.. so come, return to the root of the root of your own self' (Harvey 1994: 51). return to text

4. I began to identify this rich vein of testimony in The Journey of the Queer 'I' (Marsh 2006). return to text

5. See chapters 1 and 2 of Mr Isherwood Changes Trains (Marsh 2010) for a discussion of this issue. return to text

\section{Works cited}

Althusser, L 1971 'Ideology and ideological state apparatuses', in Lenin and philosophy and other essays (trans Ben Brewster), New York and London: Monthly Review Press return to text

Bruner, J 1987 'Life as narrative', Social Research 54: 13-32 return to text

Butler, J 1997 The Psychic Life of Power, Stanford: Stanford University Press return to text

Comstock, GD and SE Henking (eds) 1997 Que(e)rying religion: a critical anthology, New York: Continuum return to text

Eakin, PJ 2004 'What are we reading when we read autobiography?' Narrative 12, 2: 121-32 return to text

Eakin, PJ 2008 Living autobiographically: how we create identity in narrative, Ithaca: Cornell UP return to text

Eribon, D 2004 Insult and the Making of the Gay Self (trans. M Lucey), Durham and London: Duke University Press. [Réflections sur la question gai. Fayard, 1999] return to text

Foucault, M 1984 'What is Enlightenment?' ('Qu'est-ce que les lumières?') in P Rabinow (ed) The Foucault Reader, New York: Pantheon Books, pp32-50 return to text

Foucault, M 1994 'The Ethics of the Concern for Self as a Practice of Freedom' in P Rabinow (ed) Ethics: subjectivity and truth (trans R Hurley et al), New York: New Press, pp281-301 return to text

Fromm, E 1960 'Zen Buddhism and Psychoanalysis' in DT Suzuki, E Fromm \& R De Martino Zen Buddhism and Psychoanalysis, New York: Harper \& Row, pp77-141 return to text

Halperin, DM 1995 Saint Foucault: Towards a Gay Hagiography, New York: Oxford University Press return to text

Harvey, A 1994 Way of Passion: A Celebration of Rumi. Berkeley, CA: Frog, Ltd return to text hooks, b 1990a 'Talking back' in R Ferguson et al (eds) Out There, New York: New Museum of Contemporary Art, pp337-339 return to text

hooks, b 1990b 'Marginality as a site of resistance' in R Ferguson et al (eds) Out There, New York: New Museum of Contemporary Art, pp341-344 return to text 
Isherwood, C 1971 Kathleen and Frank, London: Methuen return to text

von Krafft-Ebing, R 1924 Psychopathia Sexualis, with especial reference to the Antipathic Sexual Instinct. A Medico-Forensic Study. English adaptation of the twelfth German edn. New York: Physicians and Surgeons Book Company

Lal, V 2010 'The Intellectual in an Age of Violence: Criticism, Ethics, and Democratic Futures'. Plenary Address. Cultural Studies of Australasia National Conference. Byron Bay, NSW (7 December) return to text

Lyotard, J-F 1986 The Postmodern Condition: A Report on Knowledge, Manchester: Manchester UP return to text

Marsh, V 2010 Mr Isherwood Changes Trains: Christopher Isherwood and the Search for the 'home self', Melbourne: Clouds of Magellan return to text

Marsh, V 2008 'Authority, Disobedience and Dissent: First-Person Testimony and the Que(e)rying of Religion' Postscripts: The Journal of Sacred Texts and Contemporary Worlds 4, 3: $233-242$

Marsh, V 2006 The Journey of the Queer 'I': Spirituality and Subjectivity in Life Narratives by Gay Men, PhD Dissertation: University of Queensland return to text

Nicholson, S 1995 'The narrative dance - a practice map for White's therapy', ANZ Journal Family Therapy 16, 1: 23-28 return to text

Salih, S (ed) with J Butler 2004 The Judith Butler reader. Malden MA and Oxford UK: Blackwell return to text

Savastano, P 2007 'Gay men as virtuosi of the holy art of bricolage and as tricksters of the sacred', Theology \& Sexuality 14, 1: 9-28 return to text

Smith, S 1993 Subjectivity, Identity, and the Body: Women's Autobiographical Practices in the Twentieth Century, Bloomington: Indiana University Press return to text

Smith, S \& J Watson 1996 Getting a Life: Everyday Uses of Autobiography, Minneapolis: University of Minnesota Press, 1996 return to text

Stewart, CB 2002 'In Paths Untrodden: Queer Spiritual Autobiography’, PhD Thesis: Case Western University, Ohio return to text

Strawson, G 2004 'Against narrativity', Ratio 17, 4: 428-452 return to text

Whitlock, G (ed) 1996 'Introduction: Disobedient subjects' in Autographs: Contemporary Australian Autobiography, St Lucia: University of Queensland Press, pp ix-xxx return to text

Victor Marsh is a writer, researcher, editor and former TV producer who returned to Australia in 2002 after 12 years in Los Angeles, where he produced stories for the sci-tech TV show, Beyond 2000. A student of comparative religion for forty years, he spent 12 years teaching meditation in a dozen countries on behalf of his guru. Originally an honours graduate from the University of Western Australia, he received his PhD in English from the University of Queensland, with a dissertation titled: "The Journey of the Queer 'I': Spirituality and Subjectivity in Life Narratives by Gay Men'. His critical biography of British writer, Christopher Isherwood, Mr Isherwood Changes Trains, was published by Clouds of Magellan in 2010. 


\section{TEXT}

Vol 15 No 1 April 2011

http://www.textjournal.com.au

Editors: Nigel Krauth \& Kevin Brophy

Text@griffith.edu.au 